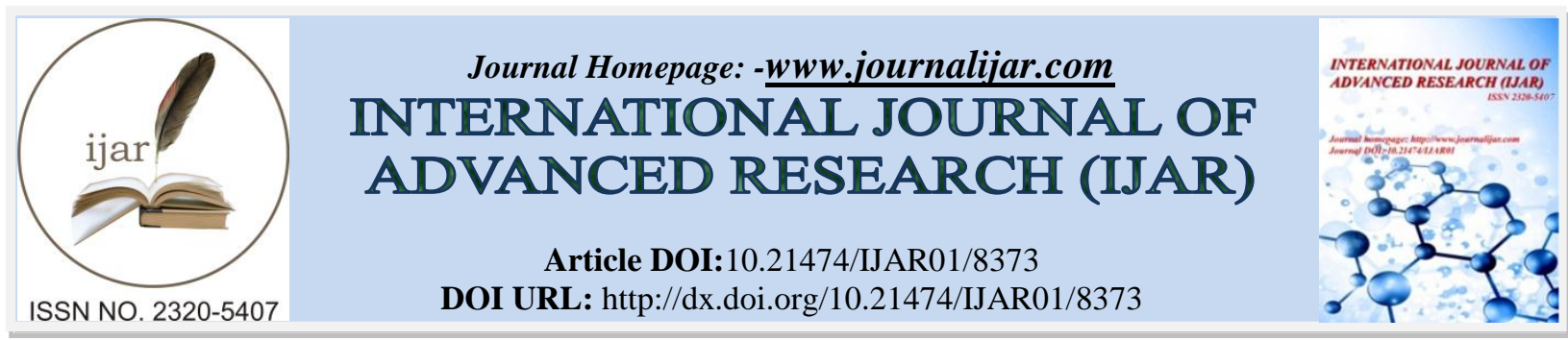

RESEARCH ARTICLE

\title{
A STUDY TO ASSESS THE EFFECTIVENESS OF YOGA THERAPY ON LEVEL OF HBA1C AMONG T-2 DIABETIC PATIENTS ADMITTED IN O.P.D AT SELECTED HOSPITAL,PUNJAB.
}

1. PhD Scholar, MAHER,Chennai.

\section{U.Poongodi ${ }^{1}$ and Susila ${ }^{2}$.}

2. Principal, Billroth College of Nursing,Chennai,Tamil Nadu.

\section{Manuscript Info}

Manuscript History

Received: 10 November 2018

Final Accepted: 12 December 2018

Published: January 2019

Key words:-

Yogatherapy, HbA1C,Type-2 diabetic patients.

\section{Abstract}

The study investigated the level of $\mathrm{HbA} 1 \mathrm{C}$ for $\mathrm{T}-2$ diabetic patients attending OPD in selected Hospital,Faridkot,Punjab.A quantitative research approach and Quasi experimental Time series design was used in this study. The main objectives of this study were to assess the level of $\mathrm{HbA} 1 \mathrm{C}$ for T-2 diabetic patients and assess the effectiveness of yoga therapy.A total number of 60 patients,attended diabetic OPD and who fulfilled the inclusion criteria and willing to participate were selected. After getting consent from the patients, the blood samples were collected from the patients and sent in to diagnostic lab.The data was analysed using descriptive and inferential statistics. The findings shows that there is a significant mean difference between the Pretest and Posttest level of $\mathrm{HbA1C}$ among Type-2 diabetic patients.Also findings shows that the yoga therapy is effective for reducing $\mathrm{HbA} 1 \mathrm{C}$ among $\mathrm{T}-2$ diabetic patients.

Copy Right, IJAR, 2017,. All rights reserved.

\section{Introduction:-}

Diabetes is a major global health problem.India now has the largest population of diabetes internationally,19 million.India is also expected to show the highet increase in prevalence internationally by 2025 (WHO report).Increase physical activity can prevent or delay the development of T-2 diabetes in high risk groups,such as those with impaired glucose tolerance .Many studies proved that yoga reduce the risks in adults with $\mathrm{T}-2$ diabetes.Now-a-days,millions and millions of people across the globe have benefited by the practice of yoga.The modern life style is as such where humans struggle with physical and physiological stress. Many chronic ailments like asthma,diabetes,B.P have found a great solution in yoga.Researchers says that yoga practices shows significant reduction in FBS,PPBS levels,insulin-glucose ratio and reduction in oral hypoglycaemic and insulin requirements.Exercise is improve glucose uptake by improving insulin sensitivity in patients with T-2 diabetes.India has the highest number of people with diabetes in the world, which is expected to increase to 101.2 million by the year 2030.It is the time to start the yoga practices in schools,colleges,community and Hospitals.Hence,people who attend yoga classes and practice it regularly in Home as a routine work,so that it will improve their life style modifications.

\section{Objectives:-}

1. To assess the level of HbA1C among T-2 diabetic patients in experimental and control group before yoga.therapy 
2. To assess the level of $\mathrm{HbA1C}$ among T-2 Diabetic patients in experimental and control group after yoga therapy.

3. To compare the level of $\mathrm{HbA1C}$ in experimental and control group of $\mathrm{T}-2$ diabetic patients.

4. To assess the effectiveness of yoga therapy after intervention.

5. To test the association between the level of $\mathrm{HbA1C}$ and selected demographic variables among T-2 diabetic patients in experimental group.

\section{Materials and Methods:-}

Quantitative Research approach,Quasi experimental (Time series design)was used.Variables are: Independent Variable: Yoga therapy, Dependent Variable: HbA1C

\section{Extraneous Variable:-}

Age,Sex,Maritalstatus,Religion,Education,Occupation,Duration of illness,Mode of treatment,Duration of taking treatment,Any medical problems, Any treatment and Practice of yoga in home.

\section{Settings of the study:-}

The study was conducted in selected areas of Hospital at Faridkot,Punjab. The Non-insulin dependent patients who regularly attend OPD for check-up and take treatment were selected.About 60 Type-2 Diabetic patients were selected for experimental and control group.The study was clearly explained patients and they were selected according to the inclusion criteria and gave their full participation. The experimental group was selected and assessed withyogatherapy and control group was selected and assessed without yogatherapy.

\section{Target population:-}

The patient diagnosed as Type-2 diabetes mellitus in the age group of 30-70 years.

\section{Accessible population:-}

The Type-2 diabetic patients who attend diabetic OPD in selected Hospital of Faridkot.

\section{Sample:-}

In this study patients diagnosed as Type-2 diabetes mellitus are selected as samples.

\section{Sample size:-}

Sample size totally consists of 60 were selected for this study.

\section{Sampling technique:-}

In this study the purposive sampling technique was used.

\section{Description of the tool:-}

\section{Part A:-}

Demographic data which includesage,gender,maritalstatus,religion,education,occupation,duration of illness,mode of treatment,duration of taking treatment, any medical problems and practice yoga.

\section{Part B:-}

Blood sample was collected for analyzing the (HbA1C) of Type-2diabetic patients.

\section{Part C:-}

Yoga therapy was teach to the Type-2 diabetic patients by using video assisted device. For Yoga therapy, 3 different types of Asanas were selected.Theseasanas are useful for Diabetic patients.The following asanas are taught to the Type-2 Diabetic patients through Video assisted device. The asanas are

1. Paschimottasana-Sitting asana

2. Janusirshasana-Sitting asana

3. Bhujangasana-Prone asana

The Video is displayed to the Type-2 diabetic patients who attend OPD for 10-15 mts.

\section{Data Collection Procedure:-}


A written permission was obtained from the Hospital authority.The study was conducted in selected Hospital.In this study the patients were selected by purposive sampling technique and who fulfil the inclusion criteria.Informed consent was obtained from the Type- 2 diabetic patients. Totally 60 Type-2 diabetic patients who attend OPD were selected.The purpose of the study was explained to the patients and confidentiality was assured to all the patients.For assessing Pre test,blood sample is collected from the patients for assessing HbA1C.Then the yogatherapy techniques were displayed through video assisted device to the Type-2 diabetic patients .The average time taken per patient was 15-20 minutes.Then $1^{\text {st }}$ post-test was conducted after 3 months. The patients are reinforced and motivated to practice yoga regularly in Home. Then $2^{\text {nd }}$ post-test was conducted after 6 months.

Data Analysis And Interpretation:-

Table 1:-Frequency and Percentage distribution of level of HbA1C among T-2 diabetic patients. $\quad \mathbf{N = 6 0}$

\begin{tabular}{|c|c|c|c|c|c|c|c|c|c|c|c|c|}
\hline \multirow[t]{3}{*}{ Level of blood sugar (HbA1C) } & \multicolumn{6}{|c|}{ Experimental group } & \multicolumn{6}{|c|}{ Control group } \\
\hline & \multicolumn{2}{|c|}{ pre test } & \multicolumn{2}{|c|}{ post test 1} & \multicolumn{2}{|c|}{ post test 2} & \multicolumn{2}{|c|}{ pre test } & \multicolumn{2}{|c|}{ post test 1} & \multicolumn{2}{|c|}{ post test 2} \\
\hline & $\mathbf{F}$ & $\%$ & $\mathbf{F}$ & $\%$ & $\mathbf{F}$ & $\%$ & $\mathbf{F}$ & $\%$ & $\mathbf{F}$ & $\%$ & $\mathbf{F}$ & $\%$ \\
\hline Normal & - & - & - & - & - & - & - & - & - & - & - & - \\
\hline High Risk of Diabetes & - & - & 1 & 3.33 & 2 & 6.67 & 1 & 3.33 & 1 & 3.33 & - & - \\
\hline Diabetes & 30 & 100 & 29 & 96.67 & 28 & 93.33 & 29 & 96.67 & 29 & 96.67 & 30 & 100 \\
\hline Total & 30 & 100 & 30 & 100 & 30 & 100 & 30 & 100 & 30 & 100 & 30 & 100 \\
\hline
\end{tabular}

Table-1 represents that in experimental group, Post test-1, 3.33\% and Post test- $2,6.67 \%$ belongs to High risk of diabetes category and Pre test,Post test-1 and Post test-2,100\%,96.67 and 93.33 belongs to diabetes category respectively.In control group,Pre test and Post test-1,3.33\% belongs to High risk of diabetes and Pre test-96.67\%, Post test-1-96.67\% and Post test-2-100\% belongs to diabetes.

Table 2a:-Paired ' $t$ '-test of experimental Pre test and $1^{\text {st }}$ and $2^{\text {nd }}$ Post test scores on HbA1C of diabetic patients. $\mathbf{N}=\mathbf{3 0}$

\begin{tabular}{|c|c|c|c|c|c|c|}
\hline \multirow{2}{*}{$\begin{array}{l}\text { Level of } \\
\text { HbA1C }\end{array}$} & \multicolumn{6}{|c|}{ Experimental group } \\
\hline & Mean & SD & Mean difference & t value & df & p value \\
\hline \multirow{2}{*}{$\begin{array}{c}\text { Pre test } \\
\text { Post-Test } 1\end{array}$} & 8.69 & 0.75 & \multirow[t]{2}{*}{0.517} & \multirow[t]{2}{*}{18.46} & \multirow[t]{2}{*}{29} & \multirow[t]{2}{*}{$0.001 * *$} \\
\hline & 8.18 & 0.74 & & & & \\
\hline \multirow{2}{*}{$\begin{array}{c}\text { Pre test } \\
\text { Post-Test } 2\end{array}$} & 8.69 & 0.75 & \multirow[t]{2}{*}{1.077} & \multirow[t]{2}{*}{27.50} & \multirow[t]{2}{*}{29} & \multirow[t]{2}{*}{$0.001 * *$} \\
\hline & 7.62 & 0.73 & & & & \\
\hline \multirow{2}{*}{$\begin{array}{l}\text { Post-Test } 1 \\
\text { Post-Test } 2\end{array}$} & 8.18 & 0.74 & \multirow[t]{2}{*}{0.560} & \multirow[t]{2}{*}{22.23} & \multirow[t]{2}{*}{29} & \multirow[t]{2}{*}{$0.001 * *$} \\
\hline & 7.62 & 0.73 & & & & \\
\hline
\end{tabular}

Table-2(a) shows that there is an gradual reduction of HbA1C from Pre test to Post test-2. In Pre test ,the mean score is 8.69 with SD 0.75 and $t$ value is 18.46 ( p-value 0.001).In Post test-2,the mean score is 7.62 with SD 0.73 and $t$ value is 22.23 ( p-value 0.001)It shows Highly Significant difference between Pre test and Post test in experimental group.

Table 2b:-Paired ' $t$ '-test of control Pre test and $1^{\text {st }}$ and $2^{\text {nd }}$ Post test scores on HbA1C of diabetic patients.

\begin{tabular}{|c|c|c|c|c|c|c|}
\hline & & & & & & $\mathbf{N}=30$ \\
\hline \multirow{2}{*}{$\begin{array}{l}\text { Level of } \\
\text { HbA1C }\end{array}$} & \multicolumn{6}{|c|}{ Control group } \\
\hline & Mean & SD & Mean difference & t value & df & p value \\
\hline \multirow{2}{*}{$\begin{array}{c}\text { Pre test } \\
\text { Post-Test } 1\end{array}$} & 8.19 & 1.00 & \multirow[t]{2}{*}{0.040} & \multirow[t]{2}{*}{1.015} & \multirow[t]{2}{*}{29} & \multirow[t]{2}{*}{0.319} \\
\hline & 8.15 & 0.94 & & & & \\
\hline \multirow{2}{*}{$\begin{array}{c}\text { Pre test } \\
\text { Post-Test } 2\end{array}$} & 8.19 & 1.00 & \multirow[t]{2}{*}{0.040} & \multirow[t]{2}{*}{0.750} & \multirow[t]{2}{*}{29} & \multirow[t]{2}{*}{0.459} \\
\hline & 8.15 & 0.87 & & & & \\
\hline \multirow{2}{*}{$\begin{array}{l}\text { Post-Test } 1 \\
\text { Post-Test } 2\end{array}$} & 8.15 & 0.94 & \multirow[t]{2}{*}{0.000} & \multirow[t]{2}{*}{0.000} & \multirow[t]{2}{*}{29} & \multirow[t]{2}{*}{1.000} \\
\hline & 8.15 & 0.87 & & & & \\
\hline
\end{tabular}

Table-2b shows, InPre test to Post test-2. In Pre test, the mean score is 8.19 with SD 1.00 and $t$ value is 1.015 ( $\mathrm{p}$ value 0.319).In Post test-2, the mean score is 8.15 with SD 0.87 and t value is 0.000 ( $\mathrm{p}$-value 1.000). 
Table 2c:-Unpaired ' $t$ '-test of experimental and control group for Pretest ,Posttest-1 and Posttest-2 scores of HbA1C of diabetic patients. $\mathbf{N}=\mathbf{3 0}$

\begin{tabular}{|c|c|c|c|c|c|c|}
\hline \multirow{2}{*}{$\begin{array}{c}\text { Experimental and Control } \\
\text { Group }\end{array}$} & \multicolumn{6}{|c|}{ Level of HbA1C } \\
\hline & Mean & SD & Mean Difference & t value & df & $\begin{array}{c}\mathbf{p} \\
\text { value }\end{array}$ \\
\hline \multirow[t]{2}{*}{ Pre test and Pretest } & 8.69 & 0.75 & \multirow[t]{2}{*}{0.50} & \multirow[t]{2}{*}{2.19} & \multirow[t]{2}{*}{58} & \multirow[t]{2}{*}{$0.01 *$} \\
\hline & 8.19 & 1.00 & & & & \\
\hline \multirow{2}{*}{$\begin{array}{c}\text { Post-Test } 1 \text { and Post-Test } \\
1\end{array}$} & 8.18 & 0.74 & \multirow[t]{2}{*}{0.03} & \multirow[t]{2}{*}{0.106} & \multirow[t]{2}{*}{58} & \multirow[t]{2}{*}{0.457} \\
\hline & 8.15 & 0.94 & & & & \\
\hline \multirow{2}{*}{$\begin{array}{c}\text { Post-Test } 2 \text { and Post-Test } \\
2\end{array}$} & 7.62 & 0.73 & \multirow[t]{2}{*}{0.53} & \multirow[t]{2}{*}{2.59} & \multirow[t]{2}{*}{58} & \multirow[t]{2}{*}{$0.006^{*}$} \\
\hline & 8.15 & 0.87 & & & & \\
\hline
\end{tabular}

Table-2c shows that there is an significant difference in Pre test and Post test scores value between experimental and control group.InPre test,MD is 0.50 and $t$ value is 2.19 ( $p$ value- 0.01 ) and Post test-2,MD is 0.53 and $t$ value is 2.59 ( $\mathrm{p}$ value-0.006).

\section{Discussion:-}

In experimental group, Post test-1, 3.33\% and Post test-2, 6.67\% belongs to High risk of diabetes category and Pre test,Post test-1 and Post test-2,100\% belongs to diabetes category respectively.In control group,Pre test and Post test-1,3.33\% belongs to High risk of diabetes and Pre test-96.67\%, Post test-1-96.67\% and Post test-2-100\% belongs to diabetes.

The paired ' $t$ ' value shows that there is an gradual reduction of HbA1C from Pre test to Post test-2. In Pre test ,the mean score is 8.69 with SD 0.75 and t value is 18.46 ( $\mathrm{p}$-value 0.001).In Post test-2, the mean score is 7.62 with SD 0.73 and t value is 22.23 ( p-value 0.001)It shows Highly Significant difference between Pre test and Post test in experimental group.Incontrogroup,there is not much difference from Pre test to Post test-2.

In experimental group,Post test-1, there is no association between HbA1C and demographic variables except Religion and Practice yoga or exercise and Post test-2,there is no association between HbA1C and demographic variables.

\section{Conclusion:-}

The findings shows that there is an significant difference between Pre test and Post test score values and significant difference between experimental and control group.It shows that yoga therapy is effective for reducing $\mathrm{HbA} 1 \mathrm{C}$ in $\mathrm{T}$ -

2 diabetic patients.

\section{References:-}

1. Zargar AH, Wani AA, Laway BA, Masoodi SR, Wani AI, et al. (2008) Prevalence of diabetes mellitus and other abnormalities of glucose tolerance in young adults aged 20-40 years in North India (Kashmir Valley). Diabetes Res ClinPract 82: 276-281.http://www.idf.org/diabetesatlas/update-2014.

2. Ramachandran A, Ma RC, Snehalatha C (2010) Diabetes in Asia. Lancet 375: 408-418.

3. Sridhar GR, Madhu K (2002)Psychosocial aspects of diabetes.InAhuja MMS, Tripathy BB, Moses SGP et al. (eds).RSSDI Textbook of Diabetes. Research Society for the Study of Diabetes in India, Hyderabad, 737-755.

4. US Department of Health and Human Services (1996) Physical Activity and Health: A Report of the Surgeon General. Atlanta, GA: US Department of Health and Human Services, Centers for Disease Control and Prevention,National Center for Chronic Disease Prevention and Health Promotion.

5. LaMonte MJ, Blair SN, Church TS (2005) Physical activity and diabetes prevention. J ApplPhysiol (1985) 99: 1205-1213.

6. Thent ZC, Das S, Henry LJ (2013) Role of exercise in the management of diabetes mellitus: the global scenario. PLoS One 8: e80436.

7. Minuk HL, Vranic M, Marliss EB, Hanna AK, Albisser AM, et al. (1981) Glucoregulatory and metabolic response to exercise in obese noninsulin-dependent diabetes. Am J Physiol 240: E458-464.

8. Mogensen CE, Ruderman N, Devlin JT, Schneider SH, Kriska A et al.(2002) Nephropathy: early. In: Handbook of Exercise in Diabetes. (2ndedtn) American Diabetes Association, 433-449. 
9. Segal KR, Edano A, Abalos A, Albu J, Blando L, et al. (1991) Effect of exercise training on insulin sensitivity and glucose metabolism in lean, obese, and diabetic men. J ApplPhysiol (1985) 71: 2402-2411.

10. Yokoyama H, Emoto M, Fujiwara S, Motoyama K, Morioka T, et al. (2004) Short-term aerobic exercise improves arterial stiffness in type 2 diabetes. Diabetes Res ClinPract 65: 85-93.

11. Cuff DJ, Meneilly GS, Martin A, Ignaszewski A, Tildesley HD, et al. (2003) Effective exercise modality to reduce insulin resistance in women with type 2 diabetes. Diabetes Care 26: 2977-2982.

12. Sigal RJ, Kenny GP, Boulé NG, Wells GA, Prud'homme D, et al. (2007) Effects of aerobic training, resistance training, or both on glycemic control in type 2 diabetes: a randomized trial. Ann Intern Med 147: 357-369.

13. Boulé NG, Kenny GP, Haddad E, Wells GA, Sigal RJ (2003) Meta-analysis of the effect of structured exercise training on cardiorespiratory fitness in Type 2 diabetes mellitus. Diabetologia 46: 1071-1081. 